\title{
EXCHANGE RATE RISK MEASUREMENT AND MANAGEMENT: ISSUES AND APPROACHES FOR FIRMS
}

\author{
MICHAEL G. PAPAIOANNOU, Ph.D. \\ International Monetary Fund
}

\begin{abstract}
Measuring and managing exchange rate risk exposure is important for reducing a firm's vulnerabilities from major exchange rate movements, which could adversely affect profit margins and the value of assets. This paper reviews the traditional types of exchange rate risk faced by firms, namely transaction, translation and economic risks, presents the VaR approach as the currently predominant method of measuring a firm's exchange rate risk exposure, and examines the main advantages and disadvantages of various exchange rate risk management strategies, including tactical vs. strategical and passive vs. active hedging. In addition, it outlines a set of widely-accepted best practices in managing currency risk and presents some of the main hedging instruments in the OTC and exchange-traded markets. The paper also provides some data on the use of financial derivatives instruments, and hedging practices by US firms.
\end{abstract}

JEL Classification: F31, G13, G15, G32, M21

Keywords: Financial Risk, Financial Management, Foreign Exchange Hedging, Corporate Hedging Practices

Corresponding address: 700 19th Street, N.W. Washington, DC 20431

e-mail: mpapaioannou@imf.org

This paper draws heavily on various presentations on risk management while the author was the Director of Foreign Exchange Service of the WEFA Group. I thank Carlos Medeiros and a referee for helpful comments. As customary, the views expressed are those of the author and do not necessarily represent those of the I.M.F. 


\section{Introduction}

Exchange rate risk management is an integral part of every firm's decisions about foreign currency exposure (Allayannis, Ihrig, and Weston, 2001). Currency risk hedging strategies entail eliminating or reducing this risk, and require understanding of both the ways that the exchange rate risk could affect the operations of economic agents and techniques to deal with the consequent risk implications (Barton, Shenkir, and Walker, 2002). Selecting the appropriate hedging strategy is often a daunting task due to the complexities involved in measuring accurately current risk exposure and deciding on the appropriate degree of risk exposure that ought to be covered. The need for currency risk management started to arise after the breakdown of the Bretton Woods system and the end of the US dollar peg to gold in 1973 (Papaioannou, 2001).

The issue of currency risk management for non-financial firms is independent from their core business and is usually dealt with by their corporate treasuries. Most multinational firms also have risk committees to oversee the treasury's strategy in managing the exchange rate (and interest rate) risk (Lam, 2003). This shows the importance that firms attach to risk management issues and techniques. Conversely, international investors usually manage their exchange rate risk independently from the underlying assets and/or liabilities. Since their currency exposure is related to translation risks on assets and liabilities denominated in foreign currencies, they tend to consider currencies as a separate asset class requiring a currency overlay mandate (Allen, 2003).

This paper reviews the standard measures of exchange rate risk, examines best practices on exchange rate risk management, and analyzes the advantages and disadvantages of various hedging approaches for firms. It concentrates on the major types of risk affecting firms' foreign currency exposure, and pays more attention to techniques on hedging transaction and balance sheet currency risk. It is argued that prudent management of multinational firms requires currency risk hedging for their foreign transaction, translation and economic operations to avoid potentially adverse currency effects on their profitability and market valuation. The paper also provides some data on hedging practices by US firms.

The organization of the paper is as follows: In section I, we present a broad definition and the main types of exchange rate risk. In section II, we outline the main measurement approach to exchange rate risk (VaR). In section III, we review the main elements of exchange rate risk management, including hedging strategies, hedging benchmarks and performance, and best practices for managing currency risk. In section IV, we offer an overview of the main hedging instruments in the OTC and exchange-traded markets. In section $\mathrm{V}$, we provide data on the use of various derivatives instruments and hedging practices by US firms. In section VI, we conclude by offering some general remarks on the need for hedging operations based on recent currency-crisis experiences. 


\section{Definition and types of exchange rate risk}

A common definition of exchange rate risk relates to the effect of unexpected exchange rate changes on the value of the firm (Madura, 1989). In particular, it is defined as the possible direct loss (as a result of an unhedged exposure) or indirect loss in the firm's cash flows, assets and liabilities, net profit and, in turn, its stock market value from an exchange rate move. To manage the exchange rate risk inherent in every multinational firm's operations, a firm needs to determine the specific type of current risk exposure, the hedging strategy and the available instruments to deal with these currency risks.

Multinational firms are participants in currency markets by virtue of their international transactions. To measure the impact of exchange rate movements on a firm that is involved in foreign-currency denominated operations, i.e., the implied valueat-risk $(\mathrm{VaR})$ from exchange rate moves, we need to identify the type of risks that the firm is exposed to and the amount of risk encountered (Hakala and Wystup, 2002). The three main types of exchange rate risk that we consider in this paper are (Shapiro, 1996; Madura, 1989):

1. Transaction risk, which is basically cash flow risk and deals with the effect of exchange rate moves on transactional account exposure related to receivables (export contracts), payables (import contracts) or repatriation of dividends. An exchange rate change in the currency of denomination of any such contract will result in a direct transaction exchange rate risk to the firm;

2. Translation risk, which is basically balance sheet exchange rate risk and relates exchange rate moves to the valuation of a foreign subsidiary and, in turn, to the consolidation of a foreign subsidiary to the parent company's balance sheet. Translation risk for a foreign subsidiary is usually measured by the exposure of net assets (assets less liabilities) to potential exchange rate moves. In consolidating financial statements, the translation could be done either at the end-of-the-period exchange rate or at the average exchange rate of the period, depending on the accounting regulations affecting the parent company. Thus, while income statements are usually translated at the average exchange rate over the period, balance sheet exposures of foreign subsidiaries are often translated at the prevailing current exchange rate at the time of consolidation; and

3. Economic risk, which reflects basically the risk to the firm's present value of future operating cash flows from exchange rate movements. In essence, economic risk concerns the effect of exchange rate changes on revenues (domestic sales and exports) and operating expenses (cost of domestic inputs and imports). Economic risk is usually applied to the present value of future cash flow operations of a firm's parent company and foreign subsidiaries. Identification of the various types of currency risk, along with their measurement, is essential to develop a strategy for managing currency risk. 


\section{Measurement of exchange rate risk}

After defining the types of exchange rate risk that a firm is exposed to, a crucial aspect of a firm's exchange rate risk management decisions is the measurement of these risks. Measuring currency risk may prove difficult, at least with regards to translation and economic risk (Van Deventer, Imai, and Mesler, 2004; Holton, 2003). At present, a widely-used method is the value-at-risk (VaR) model. Broadly, value at risk is defined as the maximum loss for a given exposure over a given time horizon with $\mathrm{z} \%$ confidence.

The VaR methodology can be used to measure a variety of types of risk, helping firms in their risk management. However, the VaR does not define what happens to the exposure for the $(100-z) \%$ point of confidence, i.e., the worst case scenario. Since the VaR model does not define the maximum loss with $100 \%$ confidence, firms often set operational limits, such as nominal amounts or stop loss orders, in addition to VaR limits, to reach the highest possible coverage (Papaioannou and Gatzonas, 2002).

\section{Value-at-Risk calculation}

The VaR measure of exchange rate risk is used by firms to estimate the riskiness of a foreign exchange position resulting from a firm's activities, including the foreign exchange position of its treasury, over a certain time period under normal conditions (Holton, 2003). The VaR calculation depends on 3 parameters:

- The holding period, i.e., the length of time over which the foreign exchange position is planned to be held. The typical holding period is 1 day.

- The confidence level at which the estimate is planned to be made. The usual confidence levels are $99 \%$ and $95 \%$.

- The unit of currency to be used for the denomination of the VaR.

Assuming a holding period of $\mathrm{x}$ days and a confidence level of $\mathrm{y} \%$, the VaR measures what will be the maximum loss (i.e., the decrease in the market value of a foreign exchange position) over $\mathrm{x}$ days, if the $\mathrm{x}$-days period is not one of the (100-y) $\% \mathrm{x}$-days periods that are the worst under normal conditions. Thus, if the foreign exchange position has a 1-day VaR of $\$ 10$ million at the $99 \%$ confidence level, the firm should expect that, with a probability of $99 \%$, the value of this position will decrease by no more than $\$ 10$ million during 1 day, provided that usual conditions will prevail over that 1 day. In other words, the firm should expect that the value of its foreign exchange rate position will decrease by no more than $\$ 10$ million on 99 out of 100 usual trading days, or by more than $\$ 10$ million on 1 out of every 100 usual trading days.

To calculate the VaR, there exists a variety of models. Among them, the more widely-used are: (1) the historical simulation, which assumes that currency returns on a firm's foreign exchange position will have the same distribution as they had in 
the past; (2) the variance-covariance model, which assumes that currency returns on a firm's total foreign exchange position are always (jointly) normally distributed and that the change in the value of the foreign exchange position is linearly dependent on all currency returns; and (3) Monte Carlo simulation, which assumes that future currency returns will be randomly distributed.

The historical simulation is the simplest method of calculation. This involves running the firm's current foreign exchange position across a set of historical exchange rate changes to yield a distribution of losses in the value of the foreign exchange position, say 1,000, and then computing a percentile (the VaR). Thus, assuming a $99 \%$ confidence level and a 1-day holding period, the VaR could be computed by sorting in ascending order the 1,000 daily losses and taking the $11^{\text {th }}$ largest loss out of the 1,000 (since the confidence level implies that 1 percent of losses -10 losses -should exceed the VaR). The main benefit of this method is that it does not assume a normal distribution of currency returns, as it is well documented that these returns are not normal but rather leptokurtic. Its shortcomings, however, are that this calculation requires a large database and is computationally intensive.

The variance - covariance model assumes that (1) the change in the value of a firm's total foreign exchange position is a linear combination of all the changes in the values of individual foreign exchange positions, so that also the total currency return is linearly dependent on all individual currency returns; and (2) the currency returns are jointly normally distributed. Thus, for a $99 \%$ confidence level, the VaR can be calculated as:

$$
\mathrm{VaR}=-\mathrm{Vp}(\mathrm{Mp}+2.33 \mathrm{Sp})
$$

where $\mathrm{Vp}$ is the initial value (in currency units) of the foreign exchange position

$\mathrm{Mp}$ is the mean of the currency return on the firm's total foreign exchange position, which is a weighted average of individual foreign exchange positions

$\mathrm{Sp}$ is the standard deviation of the currency return on the firm's total foreign exchange position, which is the standard deviation of the weighted transformation of the variance-covariance matrix of individual foreign exchange positions (note that the latter includes the correlations of individual foreign exchange positions)

While the variance-covariance model allows for a quick calculation, its drawbacks include the restrictive assumptions of a normal distribution of currency returns and a linear combination of the total foreign exchange position. Note, however, that the normality assumption could be relaxed (Longin, 2001). When a non-normal distribution is used instead, the computational cost would be higher due to the additional estimation of the confidence interval for the loss exceeding the VaR. 
Monte Carlo simulation usually involves principal components analysis of the variance-covariance model, followed by random simulation of the components. While its main advantages include its ability to handle any underlying distribution and to more accurately assess the VaR when non-linear currency factors are present in the foreign exchange position (e.g., options), its serious drawback is the computationally intensive process.

\section{Management of exchange rate risk}

After identifying the types of exchange rate risk and measuring the associated risk exposure, a firm needs to decide whether or not to hedge these risks. In international finance, the issue of the appropriate strategy to manage (hedge) the different types of exchange rate risk has yet to be settled (Jacque, 1996). In practice, however, corporate treasurers have used various currency risk management strategies depending, ceteris paribus, on the prevalence of a certain type of risk and the size of the firm (Allen, 2003).

\subsection{Hedging strategies}

Indicatively, transaction risk is often hedged tactically (selectively) or strategically to preserve cash flows and earnings, depending on the firm's treasury view on the future movements of the currencies involved. Tactical hedging is used by most firms to hedge their transaction currency risk relating to short-term receivable and payable transactions, while strategic hedging is used for longer-period transactions. However, some firms decide to use passive hedging, which involves the maintenance of the same hedging structure and execution over regular hedging periods, irrespective of currency expectations - that is, it does not require that a firm takes a currency view.

Translation, or balance sheet, risk is hedged very infrequently and non-systematically, often to avoid the impact of possible abrupt currency shocks on net assets. This risk involves mainly long-term foreign exposures, such as the firm's valuation of subsidiaries, its debt structure and international investments. However, the long-term nature of these items and the fact that currency translation affects the balance sheet rather than the income statement of a firm, make hedging of the translation risk less of a priority for management. For the translation of currency risk of a subsidiary's value, it is standard practice to hedge the net balance sheet exposures, i.e., the net assets (gross assets less liabilities) of the subsidiary that might be affected by an adverse exchange rate move.

Within the framework of hedging the exchange rate risk in a consolidated balance sheet, the issue of hedging a firm's debt profile is also of paramount importance (Marrison, 2002; Jorion and Khoury, 1996). The currency and maturity composition of a firm's debt determines the susceptibility of its net equity and earnings to exchange rate changes. To reduce the impact of exchange rates on the volatility of earnings, 
the firm may use an optimization model to devise an optimal set of hedging strategies to manage its currency risk. Hedging the remaining currency exposure after the optimization of the debt composition is a difficult task. A firm may use tactical hedging, in addition to optimization, to reduce the residual currency risk. Moreover, if exchange rates do not move in the anticipated direction, translation risk hedging may cause either cash flow or earnings volatility. Therefore, hedging translation risk often involves careful weighing of the costs of hedging against the potential cost of not hedging.

Economic risk is often hedged as a residual risk. Economic risk is difficult to quantify, as it reflects the potential impact of exchange rate moves on the present value of future cash flows. This may require measuring the potential impact of an exchange rate deviation from the benchmark rate used to forecast a firm's revenue and cost streams over a given period. In this case, the impact on each flow may be netted out over product lines and across markets, with the net economic risk becoming small for firms that invest in many foreign markets because of offsetting effects. Also, if exchange rate changes follow inflation differentials (through PPP) and a firm has a subsidiary that faces cost inflation above the general inflation rate, the firm could find its competitiveness eroding and its original value deteriorating as a result of exchange rate adjustments that are not in line with PPP (Froot and Thaler, 1990). Under these circumstances, the firm could best hedge its economic exposure by creating payables (e.g., financing operations) in the currency in which the firm's subsidiary experiences the higher cost inflation (i.e., in the currency in which the firm's value is vulnerable).

Sophisticated corporate treasuries, however, are developing efficient frontiers of hedging strategies as a more integrated approach to hedge currency risk than buying a plain vanilla hedge to cover certain foreign exchange exposure (Kritzman, 1993). In effect, an efficient frontier measures the cost of the hedge against the degree of risk hedged. Thus, an efficient frontier determines the most efficient hedging strategy as that which is the cheapest for the most risk hedged. Given a currency view and exposure, hedging optimization models usually compare $100 \%$ unhedged strategies with $100 \%$ hedged using vanilla forwards and option strategies in order to find the optimal one. Although this approach to managing risk provides the least-cost hedging structure for a given risk profile, it critically depends on the corporate treasurer's view of the exchange rate. Note that such optimization can be used for transaction, translation or economic currency risk, provided that the firm has a specific currency view (i.e., a possible exchange rate forecast over a specified time period).

\subsection{Hedging benchmarks and performance}

Hedging performance can be measured as a distance to a given benchmark rate (Jacque, 1996). The risk embedded in the hedge is usually expressed as a VaR number 
that will be consistent with the performance measure. Hedging optimization models, as methods for optimizing hedging strategies for currency-denominated cash flows, help find the most efficient hedge for individual currency exposures, while most of them do not provide a hedging process for multiple currency hedging. Thus, both performance and VaR are measured as effective hedge rates, calculated for each hedging instrument used and the risk in terms of a confidence level. A single optimal hedging strategy is then selected by defining the risk that a firm is willing to take. This strategy is the lowest possible effective hedge rate for an acceptable level of uncertainty. In this way, when the firm's currency view entails a perception of volatility, options generate a better or similar effective hedge rate at lower uncertainty than the unhedged position. Furthermore, when local currency has a relatively high yield and low volatility, options will almost always generate a better effective hedging rate than forward hedging.

As part of the currency risk management policy, firms use a variety of hedging benchmarks to manage their hedging strategies effectively. Such benchmarks could be the hedging level (i.e., a certain percentage), the reporting period, especially for firms that use forward hedging to limit the volatility of their net equity, (e.g., quarterly or 12-month benchmarks), and budget exchange rates, depending on the prevailing accounting rules. Moreover, benchmarks enable the performance of individual hedges to be measured against that of the firm.

\subsection{Hedging and budget rates}

Budget exchange rates provide firms with a reference exchange rate level (Madura, 1989). Setting budget exchange rates is often linked to the firm's sensitivities and benchmarking priorities. After deciding on the budget rate, the corporate treasury will have to secure an appropriate hedge rate and ensure that there is minimal deviation from that hedge rate. This process will determine the frequency and instruments to be used in hedging. It should be further pointed out that persistent moves relative to the numeraire (functional) currency should be reflected in the budget rates, or strategic positioning and hedging should be considered.

Firms have different practices in setting budget exchange rates (Lam, 2003). Many corporate treasurers of multinational firms prefer to use PPP rates as budget exchange rates, often on the understanding that tactical hedging may be needed over the short-term where the forecasting performance of the PPP model is usually poor. ${ }^{1}$ However, other multinational firms prefer to set the budget rate in accordance with their sales calendar and, in turn, with their hedging strategy. For example, if a firm

1. The relative version of the PPP theory states that bilateral exchange rates would adjust to the relative price differentials of the same basket of goods traded in the two countries. 
has a quarterly sales calendar, it may decide to hedge its next year's quarterly foreign currency cash flow in such a way that it does not differ by more than a certain percentage from the cash flow in the same quarter of the previous year. Accordingly, this will necessitate four hedges per year, each of one-year tenor, with hedging being done at the end of the period, using the end-of-period exchange rate as its budget rate.

Alternatively, a firm may decide to set its budget exchange rate at the daily average exchange rate over the previous fiscal year (Barton, Shenkir, and Walker, 2002). In such cases, the firm would need to use one hedge through, perhaps, an average-based instrument like an option or a synthetic forward. This hedging operation will usually be executed on the last day of the previous fiscal year, with starting day the first day of the new fiscal year. Furthermore, a firm may also use passive currency hedging, such as hedging the average value of a foreign currency cash flow over a specified time period, relative to a previous period, through option structures available in the market. This type of hedging strategy is fairly simple and easier to monitor.

Setting budget exchange rates is also crucial for a firm's pricing strategy, in addition to their importance for defining the benchmark hedging performance and tenor of a hedge (as the latter generally match cash flow hedging requirements). However, the budget exchange rate used to forecast cash flows needs to be close to the spot exchange rate in order to avoid possible major changes in the firm's pricing strategy or to reconsider its hedging strategy. In this connection, it should be noted that forecasting future exchange rates is a key aspect of a firm's pricing strategy (Papaioannou, 1989). Since it has been well-documented that forward rates are poor predictors of future spot rates, structural or time-series exchange rate models need to be employed for such an endeavor (Bansal and Dahlquist, 2000; Fama, 1984). This becomes evident if we compare a firm's net cash flows estimated by using the forecast rate and the future spot exchange rate. For an investment in a foreign subsidiary, moreover, the budget exchange rate is often the accounting rate, i.e., the exchange rate at the end of the previous fiscal year.

\subsection{Best practices for exchange rate risk management}

For their currency risk management decisions, firms with significant exchange rate exposure often need to establish an operational framework of best practices (Allen, 2003; Jacque, 1996). These practices or principles may include:

1. Identification of the types of exchange rate risk that a firm is exposed to and measurement of the associated risk exposure. As mentioned before, this involves determination of the transaction, translation and economic risks, along with specific reference to the currencies that are related to each type of currency risk. In addition, measuring these currency risks - using various models (e.g. VaR ) - is another critical element in identifying hedging positions. 
2. Development of an exchange rate risk management strategy. After identifying the types of currency risk and measuring the firm's risk exposure, a currency strategy needs to be established for dealing with these risks. In particular, this strategy should specify the firm's currency hedging objectives - whether and why the firm should fully or partially hedge its currency exposures. Furthermore, a detailed currency hedging approach should be established. It is imperative that a firm details the overall currency risk management strategy on the operational level, including the execution process of currency hedging, the hedging instruments to be used, and the monitoring procedures of currency hedges.

3. Creation of a centralized entity in the firm's treasury to deal with the practical aspects of the execution of exchange rate hedging. This entity will be responsible for exchange rate forecasting, the hedging approach mechanisms, the accounting procedures regarding currency risk, costs of currency hedging, and the establishment of benchmarks for measuring the performance of currency hedging. (These operations may be undertaken by a specialized team headed by the treasurer or, for large multinational firms, by a chief dealer.)

4. Development of a set of controls to monitor a firm's exchange rate risk and ensure appropriate position taking. This includes setting position limits for each hedging instrument, position monitoring through mark-to-market valuations of all currency positions on a daily basis (or intraday), and the establishment of currency hedging benchmarks for periodic monitoring of hedging performance (usually monthly).

5. Establishment of a risk oversight committee. This committee would in particular approve limits on position taking, examine the appropriateness of hedging instruments and associated VaR positions, and review the risk management policy on a regular basis.

Managing exchange rate risk exposure has gained prominence in the last decade, as a result of the unusual occurrence of a large number of currency crises. From the corporate managers' perspective, currency risk management is increasingly viewed as a prudent approach to reducing a firm's vulnerabilities from major exchange rate movements (Van Deventer, Imai, and Mesler, 2004). This attitude has also been reinforced by recent international attention to both accounting and balance sheet risks.

\section{Hedging instruments for managing exchange rate risk}

Within the framework of a currency risk management strategy, the hedging instruments allowed to manage currency risk should be specified. The available hedging instruments are enormous, both in variety and complexity, and have followed the dramatic increase in the specific hedging needs of the modern firm (Hakala and Wystup, 2002; Jacque, 1996; Shapiro, 1996). These instruments include both OTC and exchange-traded products. Among the most common OTC currency hedging instruments are currency forwards and cross-currency swaps. Currency forwards are de- 
fined as buying a currency contract for future delivery at a price set today. Two types of forwards contracts are often used: outright forwards (involving the physical delivery of currencies) and non-deliverable forwards (which are settled on a net cash basis). With forwards, the firm is fully hedged. However, the high cost of forward contracts and the risk of the exchange rate moving in the opposite direction are serious disadvantages.

The two most commonly used cross-currency swaps are the cross-currency coupon swap and the cross-currency basis swaps. The cross-currency coupon swap is defined as buying a currency swap and at the same time paying fixed and receiving floating interest payments. Its advantage is that it allows firms to manage their foreign exchange rate and interest rate risks, as they wish, but it leaves the firm that buys this instrument vulnerable to both currency and interest rate risk. Cross-currency basis swap is defined as buying a currency swap and at the same time paying floating interest in a currency and receiving floating in another currency. This instrument, while assuming the same currency risk as the standard currency swap, has the advantage that it allows a firm to capture prevailing interest rate differentials. However, the major disadvantage is that the primary risk for the firm is interest rate risk rather than currency risk.

For exchange-traded currency hedging instruments, the main types are currency options and currency futures. The development of various structures of currency options has been very rapid, and is attributed to their flexible nature. The most common type of option structure is the plain vanilla call, which is defined as buying an upside strike in an exchange rate with no obligation to exercise (Allen, 2003). Its advantages include its simplicity, lower cost than the forward, and the predicted maximum loss - which is the premium. However, its cost is higher than other sophisticated options structures such as call spreads (buy an at-the-money call and sell a low delta call).

Currency futures are exchange-traded contracts specifying a standard volume of a particular currency to be exchanged on a specific settlement date. They are similar to forward contracts in that they allow a firm to fix the price to be paid for a given currency at a future point in time. Yet, their characteristics differ from forward rates, both in terms of the available traded currencies and the typical (quarterly) settlement dates. However, the price of currency futures will normally be similar to the forward rates for a given currency and settlement date.

Comparing currency forward and currency futures markets, the size of the contract and the delivery date are tailored to individual needs in the forward market (i.e., determined between a firm and a bank), as opposed to currency futures contracts that are standardized and guaranteed by some organized exchange. While there is no separate clearing-house function for forward markets, all clearing operations for futures markets are handled by an exchange clearing house, with daily mark-to-market settlements. In terms of liquidation, while most forward contracts are settled by 
actual delivery and only some by offset - at a cost, in contrast, most futures contracts are settled by offset and only very few by delivery. Furthermore, the price of a futures contract changes over time to reflect the market's anticipation of the future spot rate. If a firm holding a currency futures contract decides before the settlement date that it no longer wants to maintain such a position, it can close out its position by selling an identical futures contract. This, however, cannot be done with forward contracts.

Finally, since currency hedging is often costly, a firm may first consider "natural" hedging (Madura, 1989), such as (1) matching, which involves pairing suitably a multinational firm's foreign currency inflows and outflows with respect to amount and timing; (2) netting, which involves the consolidated settlement of receivables, payables and debt among the subsidiaries of a firm; and (3) invoicing in a foreign currency, which reduces transaction risk related primarily to exports and imports.

\section{Hedging practices by US firms}

According to the BIS (see Tables 1-4) and the International Swap and Derivatives Association, the OTC derivatives market has experienced an exponential growth. Even with the recent slowdown due to the special disclosure requirements of FAS 133, derivatives continue to be the main hedging instrument for most firms. However, the increased availability of derivative instruments, coupled with the advent of mark-tomarket hedge accounting (FAS 133 and IAS 39), implies an impact of derivatives on firms' financial statements which is difficult to follow.

Table 1. Notional Amounts Outstanding of OTC Derivatives by Instrument (end of year; in billions of US dollars)

\begin{tabular}{|l|r|r|r|}
\hline Instrument & \multicolumn{1}{|c|}{2002} & \multicolumn{1}{|c|}{2003} & \multicolumn{1}{c|}{2004} \\
\hline Total contracts & 141,665 & 197,167 & 248,288 \\
\hline Foreign exchange contracts & 18,448 & 24,475 & 29,575 \\
\hline Forwards and swaps & 15,222 & 18,758 & 23,460 \\
\hline Options & 3,226 & 5,717 & 6,115 \\
\hline Interest rate contracts & 101,658 & 141,991 & 187,340 \\
\hline Other contracts & 21,559 & 30,701 & 31,373 \\
\hline
\end{tabular}

Source: BIS Quarterly Review, September 2005, Table 19

Table 2. Notional Amounts Outstanding of OTC Derivatives by Currency (end of year; in billions of US dollars)

\begin{tabular}{|l|r|r|r|}
\hline Currencies & \multicolumn{1}{|c|}{2002} & \multicolumn{1}{|c|}{2003} & \multicolumn{1}{c|}{2004} \\
\hline All currencies & 18,448 & 24,475 & 29,575 \\
\hline US dollar & 16,500 & 21,429 & 25,998 \\
\hline Euro & 7,794 & 10,145 & 11,936 \\
\hline Japanese yen & 4,791 & 5,500 & 7,083 \\
\hline Pound sterling & 2,462 & 4,286 & 4,349 \\
\hline
\end{tabular}

Source: BIS Quarterly Review, September 2005, Table 20B 
Table 3. Notional Amounts Outstanding of OTC Foreign Exchange Derivatives by Maturity (end of year; in billions of US dollars)

\begin{tabular}{|l|r|r|r|}
\hline Maturity & \multicolumn{1}{|c|}{2002} & \multicolumn{1}{|c|}{2003} & \multicolumn{1}{c|}{2004} \\
\hline Total contracts & 18,448 & 24,475 & 29,575 \\
\hline Maturity of I year or less & 14,522 & 18,840 & 23,115 \\
\hline Maturity over 1 year and up to 5 years & 2,719 & 3,901 & 4,386 \\
\hline Maturity over 5 years & 1,208 & 1,734 & 2,073 \\
\hline
\end{tabular}

Source: BIS Quarterly Review, September 2005, Table 20C

Table 4. Derivative Financial Instruments Traded on Organized Exchanges by Instrument and Location (notional principal; in billions of US dollars)

\begin{tabular}{|c|c|c|c|c|c|c|c|}
\hline Instrument/ & & Amounts & Outstanding & & & Turnover & \\
\hline Location & $\begin{array}{l}2002 \\
\text { Dec. }\end{array}$ & $\begin{array}{l}2003 \\
\text { Dec. }\end{array}$ & $\begin{array}{l}2004 \\
\text { Dec. }\end{array}$ & $\begin{array}{l}2005 \\
\text { June }\end{array}$ & $\begin{array}{l}2003 \\
\text { Year }\end{array}$ & $\begin{array}{l}2004 \\
\text { Year }\end{array}$ & $\begin{array}{c}2005 \\
\text { Q2 }\end{array}$ \\
\hline \multicolumn{8}{|l|}{ Futures } \\
\hline All markets & 10,328 & 13,706 & 18,903 & 20,432 & 625,121 & 831,783 & 269,910 \\
\hline Int. rate & 9,956 & 13.124 & 18,165 & 19.678 & 588,741 & 783,140 & 254,377 \\
\hline Currency & 47 & 80 & 104 & 100 & 3,937 & 6,615 & 2,823 \\
\hline Equity ind. & 326 & 502 & 634 & 654 & 32,443 & 42,028 & 12,711 \\
\hline North Amer. & 5,871 & 7,700 & 10,466 & 11,574 & 310,200 & 440.775 & 155,490 \\
\hline Int. rate & 5.660 & 7,385 & 10,044 & 11,152 & 290,049 & 414,310 & 146,603 \\
\hline Currency & 45 & 65 & 92 & 86 & 3,562 & 6,081 & 2,622 \\
\hline Equity ind, & 166 & 250 & 331 & 335 & 16,589 & 20,384 & 6,266 \\
\hline Europe & 3,274 & 4,363 & 5,972 & 6,450 & 265,290 & 336,622 & 101,200 \\
\hline $\begin{array}{l}\text { Other } \\
\text { markets }\end{array}$ & 1.184 & 1,643 & 2,466 & 2,407 & 49.631 & 54,386 & 13,220 \\
\hline \multicolumn{8}{|l|}{ Options } \\
\hline All markets & 13,488 & 23,034 & 27,689 & 38,076 & 249,162 & 312,070 & 102,460 \\
\hline Int. rate & 11.760 & 20,794 & 24,604 & 34,109 & 205,386 & 260,056 & 87,009 \\
\hline Currency & 27 & 38 & 61 & 70 & 492 & 589 & 253 \\
\hline Equity ind. & 1,701 & 2,202 & 3,024 & 3,897 & 43,284 & 51,425 & 15,198 \\
\hline North Amer. & 7,823 & 11,804 & 17,142 & 24,250 & 131,798 & 181,496 & 64,588 \\
\hline Int. rate & 6,661 & 10,382 & 15,287 & 21,771 & 115,769 & 163,161 & 58,653 \\
\hline Currency & 21 & 19 & 41 & 33 & 276 & 346 & 134 \\
\hline Equity ind. & 1,142 & 1,404 & 1,815 & 2,447 & 15,753 & 17,988 & 5,801 \\
\hline Europe & 5,526 & 11,043 & 10,336 & 13,537 & 93,050 & 101,951 & 29,996 \\
\hline $\begin{array}{l}\text { Other } \\
\text { markets }\end{array}$ & 138 & 187 & 211 & 288 & 24,314 & 28,624 & 7,876 \\
\hline
\end{tabular}

Source: BIS Quarterly Review, September 2005, Table 23A 
Several surveys have shown certain characteristics and practices of US non-financial firms using derivatives (Bodnar and Gebhardt, 1998; Treasury Management Association, 1996; Bodnar, Hayt, Marston, and Smithson, 1995; Papaioannou, 1989). Thus, the larger the size of sales of US non-financial firms, the more likely they are to use derivatives in their risk management (Table 5).

Table 5. Use of Derivative Instruments by US Non-financial Firms

\begin{tabular}{|l|c|c|}
\hline By size of sales & $\begin{array}{c}\text { Number } \\
(\% \text { of total })\end{array}$ & $\begin{array}{c}\text { Yes } \\
(\% \text { of total })\end{array}$ \\
\hline More than \$6.5 billion & 30 & 27 \\
$(15 \%)$ & $(90 \%)$ \\
\hline \$6.5 billion - \$3.3 billion & 24 & 19 \\
& $(12 \%)$ & $17 \%)$ \\
\hline \$3.3 billion - \$1.7 billion & 28 & $(57 \%)$ \\
\hline \$1.7 billion - \$0.7 billion & $(14 \%)$ & 29 \\
\hline \$0.7 billion - \$0.3 billion & 45 & $(64 \%)$ \\
\hline Less than \$0.3 billion & $32 \%)$ & $(44 \%)$ \\
\hline Total & $(16 \%)$ & 7 \\
& 38 & $(18 \%)$ \\
\hline
\end{tabular}

Source: Bodnar and Gebhardt, 1998

Foreign currency derivatives usage is most common, with almost three-fourths of the reporting firms taking positions. The primary goal of exchange risk hedging is the minimization of the variability in cash flow and in accounting earnings, arising from the firms' operational activities and characteristics. Preoccupation with accounting earnings may be related to their role in analysts' perceptions and predictions of future earnings and in management compensation. Furthermore, it is interesting to note that US firms do not attach high importance to minimizing the variation in the market value of the firm (the present discounted value of the stream of future cash flows) when they use derivatives in risk management (Table 6).

The choice of derivative instruments for foreign exchange management by US firms is concentrated in simple instruments, with OTC currency forwards being by far the most popular instrument (over $50 \%$ of all foreign exchange derivatives instruments), OTC currency options being the second most preferred hedging instrument (around 20\% of all foreign exchange derivative instruments ) and OTC swaps being the third (around 10\%) (Table7). Forward-type (volatility elimination) instruments are used to hedge foreign exchange exposures arising from US firms' contractual 
commitments (accounts receivable/payable, and repatriations), as recommended by the international financial literature (Shapiro, 1996). Option-type instruments, on the other hand, are used to hedge uncertain foreign currency-denominated future cash flows (usually, related to anticipated transactions beyond one year and to cover economic exposures). The tendency of US firms to use OTC currency forwards rather than OTC options or swaps should mainly be attributed to the relatively higher liquidity and depth of forward markets.

Table 6. Objectives of Hedging Strategy by US Non-financial Firms (in percent)

\begin{tabular}{|l|c|c|c|c|}
\hline By size of sales & $\begin{array}{c}\text { Accounting } \\
\text { earnings }\end{array}$ & $\begin{array}{c}\text { Cash } \\
\text { flows }\end{array}$ & $\begin{array}{c}\text { Balance sheet } \\
\text { accounts }\end{array}$ & $\begin{array}{c}\text { Firm } \\
\text { value }\end{array}$ \\
\hline More than $\$ 6.5$ billion & 23 & 65 & 0 & 12 \\
\hline \$6.5 billion $-\$ 3.3$ billion & 37 & 58 & 0 & 5 \\
\hline \$3.3 billion $-\$ 1.7$ billion & 50 & 38 & 0 & 12 \\
\hline \$1.7 billion $-\$ 0.7$ billion & 66 & 34 & 0 & 0 \\
\hline Less than \$0.7 billion & 38 & 43 & 5 & 14 \\
\hline Total & 44 & 47 & 1 & 8 \\
\hline
\end{tabular}

Source: Bodnar and Gebhardt, 1998

Table 7. Choice of Foreign Exchange Instrument by US Non-financial Firms (in percent)

\begin{tabular}{|l|c|c|c|}
\hline $\begin{array}{l}\text { Instrument used } \\
\text { for foreign exchange exposures }\end{array}$ & Forwards & Options & Swaps \\
\hline $\begin{array}{l}\text { Contractual commitments } \\
\text { (accounts receivable/payable and } \\
\text { repatriations) }\end{array}$ & 83 & 8 & 8 \\
\hline Anticipated transactions of $<1$ year & 60 & 29 & 5 \\
\hline Anticipated transactions of $>1$ year & 21 & 31 & 3 \\
\hline Economic exposures & 5 & 16 & 3 \\
\hline Translation of accounts & 13 & 11 & 6 \\
\hline
\end{tabular}

Source: Bodnar and Gebhardt, 1998

The use of OTC instruments (forwards/swaps and options) is much more common than that of exchange-traded hedging instruments, with currency futures being preferred by less than $10 \%$ of US firms and currency options being preferred by a very small percentage of firms. The prevalence of OTC instruments should be attributed to firms' very specific hedging needs that can primarily be accommodated in the moreflexible OTC market.

The majority of US firms with a set frequency for revaluing derivatives do so 
on a monthly basis, with a quarter of the total firms valuing their derivatives at least weekly and a very small percentage doing so only on an annual basis (Table 8). Finally, the most common methods to evaluate the riskiness of their foreign exchange positions are stress testing of derivatives and VaR techniques.

Table 8. Frequency of Derivative Valuations by US Non-financial Firms (in percent)

\begin{tabular}{|l|c|}
\hline Daily & 17 \\
\hline Weekly & 8 \\
\hline Monthly & 36 \\
\hline Quarterly & 18 \\
\hline Annually & 4 \\
\hline As needed & 17 \\
\hline Total & 100 \\
\hline
\end{tabular}

Source: Bodnar and Gebhardt, 1998

\section{Concluding remarks}

Measuring and managing currency risk exposure are important functions in reducing a firm's vulnerabilities from major exchange rate movements. These vulnerabilities mainly arise from a firm's involvement in international operations and investments, where exchange rate changes could affect profit margins, through their effect on sources for inputs, markets for outputs and debt, and the value of assets. Prudent management of currency risk has been increasingly mandated by corporate boards, especially after the currency-crisis episodes of the last decade and the consequent heightened international attention to accounting and balance sheet risks.

In managing currency risk, multinational firms utilize different hedging strategies depending on the specific type of currency risk. These strategies have become increasingly complicated as they try to address simultaneously transaction, translation and economic risks. As these risks could be detrimental to the profitability and the market valuation of a firm, corporate treasurers, even of smaller-size firms, have become increasingly proactive in controlling these risks. Thereby, a greater demand for hedging protection against these risks has emerged and, in response, a greater variety of instruments has been generated by the ingenuity of the financial engineering industry.

This paper presents some of the main issues in the measurement and management of exchange rate risks faced by firms, with special attention to the traditional types of exchange rate risk (transaction, translation, and economic), the currently predominant methodology in measuring exchange rate risk (VaR), and the advantages 
and disadvantages of various exchange rate risk management approaches (tactical vs. strategical, and passive vs. active). It also outlines a set of widely-accepted best practices in currency risk management, and reviews the use of some of the widely-used hedging instruments in the OTC and exchange-traded markets. It also reports on the use of various derivatives instruments and hedging practices of US multinationals.

Based on the reported US data, it is interesting to note that the larger the size of a firm the more likely it is to use derivative instruments in hedging its exchange rate risk exposure; the primary goal of US firms' exchange rate risk hedging operations is to minimize the variability in their cash flow and earning accounts (mainly related to payables, receivables and repatriations); and the choice of foreign exchange derivatives instruments is concentrated in OTC currency forwards (over 50 percent of all foreign exchange derivatives used), OTC currency options (around 20 percent) and OTC currency swaps (around 10 percent). From the available exchange-traded foreign exchange hedging instruments, currency futures are preferred by less than 10 percent of US firms and currency options by around 2 percent.

Overall, it should be noted that the data on US firms are only representative of the reporting period that they refer to and are indicative of the level of sophistication of US corporate treasurers and the level of development of local derivatives markets. By no means can these stylized facts be generalized for other time periods and countries, especially those with different corporate structures and capital market development. To form a better understanding of global firms' practices in this area, more empirical studies would need to be undertaken to explore their exchange rate risk measurement and hedging behaviors.

\section{References.}

Allayannis, G., Ihrig, J., and Weston, J., 2001, Exchange-Rate Hedging: Financial vs. Operational Strategies. American Economic Review Papers and Proceedings, 91 (2), pp. 391-395.

Allen, S. L., 2003, Financial Risk Management: A Practitioner's Guide to Managing Market and Credit Risk, Hoboken, New Jersey: John Wiley and Sons.

Bank of International Settlements, 2005, Quarterly Review. Basle: BIS (September).

Bansal, R. and Dahlquist, M., 2000, The Forward Premium Puzzle: Different Tales from Developed and Emerging Economies. Journal of International Economics, 51 (June), pp 115-144.

Barton, T. L., Shenkir, W. G. and Walker, P. L., 2002, Making Enterprise Risk Management Pay Off: How Leading Companies Implement Risk Management. Brookfield, Connecticut: Fei Research Foundation.

Bodnar, G. and Gebhardt, G., 1998, Derivatives Usage in Risk Management by U.S. and German Non-Financial Firms: A Comparative Survey. NBER Working Paper No 6705, Cambridge, Massachusetts: NBER (August).

Bodnar, G. M., Hayt, G., Marston, R. C., and Smithson, C.W., 1995, Wharton Survey of Derivatives Usage by US Non-Financial Firms. Financial Management, 24 (2), pp. 104-114.

Fama, E. F., 1984, Forward and Spot Exchanges. Journal of Monetary Economics, 14 (3), pp. 319338.

Froot, K. and Thaler, R., 1990, Anomalies: Foreign Exchange. Journal of Economic Perspectives, 4 (3), pp. 179-192. 
Jacque, L., 1996, Management and Control of Foreign Exchange Risk. Norwell, Massachusetts: Kluwer Academic Publishers.

Jorion, P., and Khoury, S.J., 1996, Financial Risk Management: Domestic and International Dimensions. Cambridge, Massachusetts: Blackwell Publishers.

Hakala, J., and Wystup, U., 2002, Foreign Exchange Risk: Models, Instruments, and Strategies. London: Risk Publications.

Holton, G. A., 2003, Value-at-Risk: Theory and Practice. San Diego, California: Academic Press.

International Swaps and Derivatives Association, Inc, 2001, http://www.isda.org/statistics/recent. html.

Kritzman, M., 1993, The Optimal Currency Hedging Policy with Biased Forward Rates. Journal of Portfolio Management, 19 (4), pp. 94-101.

Lam, J., 2003, Enterprise Risk Management: From Incentives to Controls. Hoboken, New Jersey: John Wiley and Sons.

Longin, F. M., 2001, Beyond the VaR. The Journal of Derivatives, pp. 36-48 (Summer).

Marrison, C., 2002, The Fundamentals of Risk Measurement, New York: McGraw Hill.

Papaioannou, M., 2001, Volatility and Misalignments of EMS and Other Currencies During 19741998. In J. Jay Choi and Jeffrey M. Wrase (eds), European Monetary Union and Capital Markets, International Finance Review, 2, Amsterdam: Elsevier Science, pp. 51-96.

Papaioannou, M., 1989, The Use of Derivatives Instruments by Multinational Firms: Some Survey Results. Bala Cynwood, Pennsylvania: The WEFA Group.

Papaioannou, M., and Gatzonas, E. K., 2002, Assessing Market and Credit Risk of Country Funds: A Value-at-Risk Analysis. In J. Jay Choi and Michael R. Powers (eds), Global Risk Management: Financial, Operational and Insurance Strategies, International Finance Review, 3, Amsterdam: Elsevier Science, pp. 61-79.

Madura, J, 1989, International Financial Management, $2^{\text {nd }}$ Edition. St. Paul, Minnesota: West Publishing Company.

Shapiro, A. C, 1996, Multinational Financial Management, $5^{\text {th }}$ Edition. Hoboken, New Jersey: John Wiley and Sons.

Treasury Management Association, 1996, Results of the 1996 Survey Questionnaire on Disclosure of Accounting Policies and Market Risk Relative to Derivative Financial and Commodities Instruments (October).

Van Deventer, D.R., Imai, K., and Mesler, M., 2004, Advanced Financial Risk Management: Tools and Techniques for Integrated Credit Risk and Interest Rate Risk Management. Hoboken, New Jersey: John Wiley and Sons. 